\title{
Environment and host as large-scale controls of ectomycorrhizal fungi
}

Article

Accepted Version

van der Linde, S., Suz, L. M., Orme, C. D. L., Cox, F., Andreae, H., Asi, E., Atkinson, B., Benham, S., Carroll, C., Cools, N., De Vos, B., Dietrich, H.-P., Eichhorn, J., Gehrmann, J., Grebenc, T., Gweon, H. S., Hansen, K., Jacob, F., Kristöfel, F., Lech, P., Manninger, M., Martin, J., Meesenburg, H., Merilä, P., Nicolas, M., Pavlenda, P., Rautio, P., Schaub, M., Schröck, H.-W., Seidling, W., Šrámek, V., Thimonier, A., Thomsen, I. M., Titeux, H., Vanguelova, E., Verstraeten, A., Vesterdal, L., Waldner, P., Wijk, S., Zhang, Y., Žlindra, D. and Bidartondo, M. I. (2018) Environment and host as large-scale controls of ectomycorrhizal fungi. Nature, 558. pp. 243-248. ISSN 00280836 doi: https://doi.org/10.1038/s41586-018-0189-9 Available at https://centaur.reading.ac.uk/77579/

It is advisable to refer to the publisher's version if you intend to cite from the work. See Guidance on citing.

To link to this article DOI: http://dx.doi.org/10.1038/s41586-018-0189-9

Publisher: Nature Publishing Group

Publisher statement: In the HTML version of this Article, author 'Filipa Cox' had no affiliation in the author list, although she was correctly associated with affiliation 3 (Earth \& Environmental Sciences, University of Manchester, Manchester, UK) in the PDF. In addition, the blue circles for 'oak' were missing 
from Extended Data Fig. 1. These errors have been corrected online.

All outputs in CentAUR are protected by Intellectual Property Rights law, including copyright law. Copyright and IPR is retained by the creators or other copyright holders. Terms and conditions for use of this material are defined in the End User Agreement.

\section{www.reading.ac.uk/centaur}

\section{CentAUR}

Central Archive at the University of Reading

Reading's research outputs online 


\section{Environment and host as large-scale controls of ectomycorrhizal fungi}

\section{Authors}

4 Sietse van der Linde ${ }^{1,2,3}$, Laura M. Suz ${ }^{2}$, C. David L. Orme ${ }^{1}$, Filipa Cox ${ }^{4}$, Henning Andreae ,

5 Endla Asi ${ }^{6}$, Bonnie Atkinson ${ }^{1,2}$, Sue Benham ${ }^{7}$, Christopher Carroll $^{1}$, Nathalie Cools ${ }^{8}$, Bruno

$6 \operatorname{De~Vos}^{8}$, Hans-Peter Dietrich ${ }^{9}$, Johannes Eichhorn ${ }^{10}$, Joachim Germann ${ }^{11}$, Tine Grebenc ${ }^{12}$,

7 Hyun S. Gweon ${ }^{13}$, Karin Hansen ${ }^{14}$, Frank Jacob ${ }^{15}$, Ferdinand Kristöfel ${ }^{16}$, Paweł Lech ${ }^{17}$,

8 Miklós Manninger ${ }^{18}, \operatorname{Jan}_{\text {Martin }^{19}}$, Henning Meesenburg ${ }^{10}$, Päivi Merilä $^{20}$, Manuel Nicolas ${ }^{21}$,

9 Pavel Pavlenda ${ }^{22}$, Pasi Rautio ${ }^{23}$, Marcus Schaub ${ }^{24}$, Hans-Werner Schröck ${ }^{25}$, Walter

10 Seidling $^{26}$, Vít Šrámek ${ }^{27}$, Anne Thimonier ${ }^{24}$, Iben Margrete Thomsen ${ }^{28}$, Hugues Titeux ${ }^{29}$,

11 Elena Vanguelova ${ }^{7}$, Arne Verstraeten $^{30}$, Lars Vesterdal $^{28}$, Peter Waldner $^{24}$, Sture Wijk ${ }^{31}$,

12 Yuxin Zhang $^{1}$, Daniel Žlindra ${ }^{12}$, Martin I. Bidartondo ${ }^{1,2}$

$14{ }^{1}$ Life Sciences, Imperial College London, Silwood Park, Ascot SL5 7PY, UK.

$15{ }^{2}$ Comparative Plant and Fungal Biology, Royal Botanic Gardens, Kew TW9 3DS, UK.

$16{ }^{3}$ Forest Research, Ecosystems, Society and Biosecurity, Alice Holt Lodge, Farnham GU35

17 4LH, UK (present address).

$18{ }^{4}$ Earth \& Environmental Sciences, University of Manchester, Manchester M13 9PL, UK.

$19{ }^{5}$ Public Enterprise Sachsenforst, Kompetenzzentrum Wald und Forstwirtschaft, Bonnewitzer

20 Straße 34, 01796 Pirna, Germany.

$21{ }^{6}$ Estonian Environment Agency, Mustamäe tee 33, Tallinn, Estonia 10616.

$22{ }^{7}$ Forest Research, Forestry and Climate Change, Alice Holt Lodge, Farnham GU35 4LH, UK.

$23 \quad{ }^{8}$ Nature and Forest Research Institute, Environment and Climate, Gaverstraat 4, 9500

24 Geraardsbergen, Belgium. 
$25{ }^{9}$ Bavarian State Forestry Institute, Hans-Carl-von-Carlowitz-Platz 1, D-85354 Freising,

26 Germany.

$27{ }^{10}$ Northwest German Forest Research Institute, Grätzelstrasse 2, D-37079 Göttingen,

28 Germany.

$29{ }^{11}$ Landesamt für Natur Umwelt und Verbraucherschutz Nordrhein-Westfalen, Leibnitzstrasse

$30 \quad 10,45659$ Recklinghausen, Germany.

$31{ }^{12}$ Slovenian Forestry Institution, Večna pot 2, SI-1000 Ljubljana, Slovenia.

$32{ }^{13}$ Biological Sciences, University of Reading, Reading RG6 6UR, UK.

$33{ }^{14}$ IVL Swedish Environmental Research Institute, 10031 Stockholm, Sweden.

$34{ }^{15}$ Staatsbetrieb Sachsenforst, Referat 43, Bonnewitzer Str. 34, 01796 Pirna, Germany.

$35 \quad{ }^{16}$ Federal Research and Training Centre for Forests, Natural Hazards and Landscape (BFW)

36 Seckendorff-Gudent-Weg 8, 1131 Wien, Austria.

$37{ }^{17}$ Forest Research Institute, Sękocin Stary, Braci Leśnej 3, 05-090 Raszyn, Poland.

$38{ }^{18}$ NARIC Forest Research Institute, Várkerület 30/a, 9600 Sárvár, Hungary.

$39{ }^{19}$ Landesforstanstalt M-V BT: FVI, Zeppelinstr. 3, 19061 Schwerin, Germany.

$40{ }^{20}$ Natural Resources Institute Finland, Paavo Havaksentie 3, 90570 Oulu, Finland.

$41{ }^{21}$ Office National des Forêts, Recherche-Développement-Innovation, Bâtiment B, Boulevard

42 de Constance, 77300 Fontainebleau, France.

$43 \quad{ }^{22}$ National Forest Centre, T.G. Masaryka 22, 96092 Zvolen, Slovakia.

$44 \quad{ }^{23}$ Natural Resources Institute Finland, Eteläranta 55, FI-96301 Rovaniemi, Finland.

$45{ }^{24}$ Swiss Federal Institute for Forest, Snow and Landscape Research, Zürcherstrasse 111, CH-

468903 Birmensdorf, Switzerland.

$47{ }^{25}$ Forschungsanstalt für Waldökologie und Forstwirtschaft, Hauptstr. 16, 67705 Trippstadt, 48 Germany. 
${ }^{26}$ Thünen Institute of Forest Ecosystems, Alfred-Möller-Str. 1, Haus 41/42, 16341

50 Eberswalde, Germany.

$51 \quad{ }^{27}$ Forestry and Game Management Research Institute, Strnady 136, 25202 Jíloviště, Czech

52 Republic.

$53{ }^{28}$ Geosciences and Natural Resource Management, University of Copenhagen, Rolighedsvej

54 23, DK-1958 Frederiksberg C, Denmark.

$55{ }^{29}$ University of Louvain, Earth and Life Institute, Croix du Sud 2, 1348 Louvain-la-Neuve, 56 Belgium.

$57{ }^{30}$ Instituut voor Natuur- en Bosonderzoek, Kliniekstraat 25, 1070 Brussels, Belgium.

$58{ }^{31}$ Swedish Forest Agency, S-551 83 Jönköping, Sweden.

60 Explaining the large-scale diversity of soil organisms that drive biogeochemical

61 processes and their responses to environmental change is critical. However, identifying

62 consistent drivers of below-ground diversity and abundance at large spatial scales

63 remains problematic for some soil organisms. We investigated a major guild, the

64 ectomycorrhizal fungi, at unprecedented scale and resolution across European forests to

65 explore key biotic and abiotic predictors, and to identify dominant responses and

66 thresholds across complex environmental gradients. Here we show the impact of 38

67 host, environment, climate and geographic variables on ectomycorrhizal diversity, and

68 we define thresholds of community change for key variables. We quantify host

69 specificity and reveal plasticity in functional traits involved in soil foraging across

70 gradients. We conclude that environmental and host factors explain most variation in

71 ectomycorrhizal diversity, the environmental thresholds used as major ecosystem

72 assessment tools need strong adjustment, and the importance of specificity and

73 plasticity below-ground has been underappreciated. 
74 The main projected impacts of environmental change on forest processes stem from global

75 and regional perturbations in the carbon $(\mathrm{C})$ and nitrogen $(\mathrm{N})$ cycles $^{1,2}$ and declines in soil

76 biodiversity $^{3,4}$. Globally, mycorrhizal mutualisms mediate soil processes in terrestrial

77 ecosystems $^{5}$ and are major drivers of ecosystem $\mathrm{C}$ and $\mathrm{N}$ dynamics $^{6}$. Soil $\mathrm{C}$ sequestration ${ }^{7,8}$,

78 tree population dynamics ${ }^{9}$ and mitigation of $\mathrm{CO}_{2}$ fertilization ${ }^{10}$ have recently been linked to

79 ectomycorrhizal (EM) symbioses, ubiquitous drivers of photosynthetic $\mathrm{C}$ exchange for soil

80 nutrients across temperate and boreal forests ${ }^{11}$.

81 How changes in ecosystem processes are underpinned by EM fungi is poorly understood, but

82 likely large-scale effects of those changes, e.g. deteriorating tree mineral nutrition and health,

83 are being observed ${ }^{12,13}$. Various ecological processes are only apparent at large spatial

84 scales $^{14}$, and there is concern about lacking baseline EM distribution data against which to

85 assess effects of global change ${ }^{15,16}$. Ectomycorrhizal research has emphasized laboratory or

86 local-scale studies, often reliant on few culturable fungi, to provide mechanistic

87 understanding of symbiotic physiology. However, determinants of EM diversity at local

88 scales are not necessarily their primary drivers at larger scales ${ }^{17}$, and EM communities are

89 often dominated by hardly culturable and non- or inconspicuously-fruiting fungi ${ }^{18}$.

90 Furthermore, EM community composition, richness, fine root biomass and morphology ${ }^{19-21}$

91 and fungal above-ground fruiting ${ }^{22}$ indicate different large-scale patterns and responses from

92 plants and animals; and EM richness increases with sample area more than for microbes ${ }^{17,23}$.

93 Consequently, there have been repeated calls for unbiased, large-scale, molecular, ecosystem-

94 level baseline data on EM fungi ${ }^{15,18,20,24}$. Elucidating large-scale EM diversity is crucial for

95 appropriate experimental design in ecosystem science and model organism selection for

96 experimental and comparative biology 25 .

97 Unlike multiple local-scale studies where EM fungi are strongly determined by soil

98 environment ${ }^{26,27}$, recent large-scale biogeographical studies report that, other than host 
99 identity, soil, climate and atmospheric deposition explain remarkably limited variability ${ }^{28-33}$

100 (Supplementary Information Table 1). Most EM fungi are thought to have broad host ranges,

101 even though specialists can be widespread; but specificity is rarely quantified below-ground

102 at large scales ${ }^{34}$.

103 Current EM environmental thresholds rarely integrate occurrence, abundance and

104 directionality of taxon responses, statistical analysis of large-scale standardized datasets, or

105 studies of low pollution sites ${ }^{16,35,36}$. Critical loads are essential tools for international

106 atmospheric emissions control ${ }^{37,38}$, but for EM fungi they differ markedly between Europe

107 and North America ${ }^{36}$. In addition, EM physiological and morphological plasticity are thought

108 to enhance soil nutrient uptake of trees across environmental gradients ${ }^{39}$; however, foraging-

109 related functional traits are assumed fixed at species- or genus-levels. Wide gradients with

110 abundant observations are needed to link plasticity and environment.

111 We conducted a detailed mycorrhizal analysis using one of the world's largest and most

112 intensive long-term monitoring networks of soil, atmospheric and vegetation parameters. We

113 analysed 38 variables at 137 plots in 20 European countries across strong environmental

114 gradients. We expected to (1) disentangle significant variability explained by co-varying

115 climatic, soil and atmospheric deposition factors, (2) test the generality of host specificity, (3)

116 detect precise thresholds of mycorrhizal change to inform environmental policy, and (4) infer

117 trait plasticity linked to key environmental gradients.

119 Results

120 We examined 29,664 ectomycorrhizas from 9,888 soil cores from 103 plots of ca. 0.25 ha in

12118 European countries. Including data from 34 plots from Cox et al. ${ }^{18}$ and Suz et al. ${ }^{16}$,

122 resulted in 39,621 ectomycorrhizas from 137 plots in 20 countries across ca. 5.5 million $\mathrm{km}^{2}$

123 (Fig. 1). After removing short low-quality (12,038), chimeric (231), non-mycorrhizal (848) 
124 and unknown $(1,308)$ ITS DNA sequences, we retained 25,196 resulting in 1,406 EM fungal

125 operational taxonomic units (OTUs), 82\% Basidiomycota and 18\% Ascomycota (Fig 2); 914

126 were recorded more than once, and $90 \%$ were identified to genus or a higher taxonomic level,

127 of which $47 \%$ were identified to species.

\section{Composition and specificity}

130 We explained $38 \%$ of variance in community composition with forward-selected variables

131 according to the Akaike Information Criterion (AIC). Variables were divided in four

132 partitions: host variables, soil+deposition, climate, and geographic distance (Supplementary

133 Table 2). Nine host variables explained most overall community variance (23\%), followed by

134 soil+deposition (21\%), geographic distance (14\%) and climatic variables (12\%). The

135 partitions shared $20 \%$ of overall explained variance (Fig. 3).

136 We used global non-metric multidimensional scaling (NMDS) ordinations to visualize EM

137 fungal community composition and we fitted environmental variables to the ordination to

138 find the most influential variables (Extended Data Fig. 1, Extended Data Table 1). Thus, we

139 identified five key variables for subsequent analyses: $\mathrm{N}$ throughfall deposition $\left(\mathrm{N}_{\mathrm{TFD}}\right)$, forest

140 floor $\mathrm{pH}$, mean annual air temperature (MAT), K throughfall deposition $\left(\mathrm{K}_{\mathrm{TFD}}\right)$ and foliar $\mathrm{N}: \mathrm{P}$

$141 \operatorname{ratio}\left(\mathrm{N}: \mathrm{P}_{\mathrm{F}}\right)$.

142 Almost two-thirds (62\%) of ectomycorrhizas correspond to fungi that produce above-ground

143 mushroom-like fruitbodies, the rest produce inconspicuous truffles, crusts or sclerotia. Based

144 on abundance, $48 \%$ were generalists and $52 \%$ specialists to coniferous or broadleaf hosts.

145 Only $7 \%$ of ectomycorrhizas were from specialists to one host tree species. Of the 88 OTUs

146 forming 50 or more ectomycorrhizas, $41 \%$ were generalists and $60 \%$ coniferous or broadleaf

147 specialists; eleven OTUs (12.5\%) were specific to one host species. 
150 Threshold indicator species analyses identified decreasing (z-) and increasing indicator OTUs

$151\left(\mathrm{z}^{+}\right)$for all five key environmental variables (Fig. 4, Extended Data Fig. 2). We identified

152 environmental thresholds of EM fungal community change by cumulating $\mathrm{z}-$ and $\mathrm{z}+$ change

153 points. For $\mathrm{N}_{\text {TFD }}$ we found a sum(z-) peak at $5.8 \mathrm{~kg} \mathrm{~N} \mathrm{ha}^{-1} \mathrm{yr}^{-1}$ and a sum( $\left.\mathrm{z}^{+}\right)$peak at $15.5 \mathrm{~kg}$

$154 \mathrm{~N} \mathrm{ha}^{-1} \mathrm{yr}^{-1}$. For $\mathrm{N}: \mathrm{P}_{\mathrm{F}}$ we detected peaks at 10.2 and 13.3 for $\operatorname{sum}(\mathrm{z}-)$ and $\operatorname{sum}\left(\mathrm{z}^{+}\right)$,

155 respectively. We found a sum(z-) peak at $6.9 \mathrm{~kg} \mathrm{~K} \mathrm{ha}^{-1} \mathrm{yr}^{-1}$ and an indistinct sum( $\left(\mathrm{z}^{+}\right)$peak at

$15621.7 \mathrm{~kg} \mathrm{~K} \mathrm{ha}^{-1} \mathrm{yr}^{-1}$ for $\mathrm{K}_{\mathrm{TFD}}$. There was a distinct peak for forest floor $\mathrm{pH}$ for sum(z-) and

$157 \operatorname{sum}\left(\mathrm{z}^{+}\right)$at 3.8. Indicator OTUs showed a clear threshold of change for MAT, with a $7.4^{\circ} \mathrm{C} \mathrm{z}^{-}$

158 peak and a distinct $9.1^{\circ} \mathrm{C} \mathrm{z}+$ peak. Most z- for $\mathrm{N}_{\mathrm{TFD}}, \mathrm{N}: \mathrm{P}_{\mathrm{F}}, \mathrm{K}$ deposition, forest floor $\mathrm{pH}$ and

159 MAT were conifer specialists while all $\mathrm{z}+$ were generalists or broadleaf associates.

160 Generally, threshold values based on accumulated change-points of individual taxa were less

161 pronounced at genus than OTU level (Extended Data Fig. 3).

162 The observed frequencies of ectomycorrhizas with emanating hyphae and those with

163 rhizomorphs differed significantly between tree species $(P<0.0001, \mathrm{df}=3)$ and soil types $(P$

$164<0.0001, \mathrm{df}=5$; Extended Data Table 2ab); hyphal frequencies were higher than expected

165 with beech and spruce and in Fe-Al soils, respectively. Thirty of the 88 most abundant OTUs

166 ( $\geq 50$ ectomycorrhizas) showed morphological plasticity and 26 of them were also indicators

167 for a key environmental variable. The change in morphology of 17 of those EM taxa was

168 significantly related with at least one environmental variable (Extended Data Tables 3a, 4a).

169 Morphological plasticity related to at least one variable was found within 12 OTUs when a

170 more stringent 99\% sequence similarity was used (Extended Data Tables 3b, 4b).

171 Intraspecific plasticity of individual indicator EM fungi does not necessarily follow overall

172 community morphological changes where logistic regressions showed that mean $\mathrm{N}_{\text {TFD }}$ was

173 positively related with hyphal presence $(P<0.0001)$. There was negative correlation between 
174 hyphal presence and forest floor $\mathrm{pH}, \mathrm{N}: \mathrm{P}_{\mathrm{F}}$ and $\mathrm{K}_{\mathrm{TFD}}$, but no correlation with MAT (Extended

175 Data Table 5). Community-wide, we found negative correlation between rhizomorph

176 presence and all tested environmental variables (Extended Data Table 5).

\section{Discussion}

179 This is the first large-scale high-resolution study of diversity and distribution of below-

180 ground tree symbionts covering all major European climatic regions for the most abundant

181 tree species. We explain considerable large-scale mycorrhizal diversity with an

182 unprecedented range and quality of environmental, host-related, climatic and geographic

183 variables. We identify large-scale environmental predictors, show the dominance of host

184 specificity, determine environmental indicators and new thresholds of change, and reveal

185 morphological plasticity along environmental gradients. These findings serve as a baseline to

186 assess future change and resilience.

187 Host-related, soil and atmospheric deposition variables were the most important predictors of

188 EM community structure across Europe. Four recent large-scale studies ${ }^{29,31-33}$ found these

189 variables to be minor predictors, even though in local-scale studies soil environment shows

190 strong effects ${ }^{26,27}$. We distinguished five key environmental variables: $\mathrm{N}_{\mathrm{TFD}}, \mathrm{N}: \mathrm{P}_{\mathrm{F}}$, forest

191 floor $\mathrm{pH}, \mathrm{K}_{\mathrm{TFD}}$ and MAT. Across previous large-scale studies, there is agreement that host

192 species and soil $\mathrm{pH}$ are important, but results about other variables disagree (Supplementary

193 Information Table 1). Inconsistent large-scale drivers of diversity and abundance have been

194 reported across different microbes ${ }^{40}$, but host is also fundamental for prokaryotes at

195 macroecological scales ${ }^{41}$. Environmental effects on EM fungi in previous studies have

196 probably been confounded by: (i) environmental variables from modelled or extrapolated

197 regional sources; (ii) non-standardized sampling and spatial pseudo-replication; (iii) indirect

198 assignment of mycorrhizal status and traits using databases (e.g. UNITE, FunGuild, 
199 DEEMY); (iv) semi-quantitative analysis of short DNA sequences; and (v) pooling DNA

200 samples from root hyphae, soil hyphae and dormant propagules even though EM spore banks

201 differ strongly from active communities on roots at local and large scales ${ }^{42}$, and ephemeral

202 above-ground reproductive structures and soil hyphae correspond weakly with active

203 communities on roots ${ }^{43,44}$. As a result, up to $90 \%$ of variation in EM diversity at large scales

204 has remained unexplained by environmental models ${ }^{33}$. The approach used here is considered

205 more robust $^{45}$ and generates higher quality data ${ }^{46}$, but had yet to be scaled up due to technical

206 challenges. The large unexplained part of community structure may be attributed to

207 unaccounted factors such as disturbance, management history, stochasticity, interactions

208 among variables masking individual effects, measurement and analytical errors, exclusion of

209 rare species, seasonality, using taxonomic instead of functional diversity, and/or not covering

210 complete gradients of each variable across whole geographic ranges of hosts and fungi. In our

211 study, conifers have larger distribution and thus cover larger environmental gradients that

212 likely explain the different number of environmental variables linked to community

213 dissimilarities among hosts.

214 Host-related variables strongly influence EM fungal communities, thus symbiosis plays a

215 major role in shaping EM distributions. Studies on host specificity of EM fungi at large scales

216 have been mainly based on fruitbody surveys and thus assess specificity on taxonomic rather

217 than abundance levels ${ }^{47}$. Host generalism is considered the rule ${ }^{48}$, but intensive below-ground

218 analysis indicates EM fungal specificity to the most common European trees matches or

219 exceeds generalism on taxonomic and relative abundance levels, particularly for conifers. We

220 find more conifer specialists and they respond strongly to environmental gradients; the

221 implications of specificity and abundance merit investigation, as they can reflect,

222 respectively, more $\mathrm{e}^{34,49}$ and less ${ }^{50}$ efficient nutritional mutualisms. 
223 We use threshold indicator taxon analyses for the first time for fungi at a continental scale to

224 identify distinct EM responses to key environmental variables and clear thresholds of change.

225 Indicator species emerged for all key environmental variables, and several EM taxa were

226 indicators for more than one. Different fungi within a family, and even a genus, can be both

227 positive and negative indicators for a variable; for instance, Thelephora terrestris and

228 Tomentella castanea are negative and positive indicators for $\mathrm{N}: \mathrm{P}_{\mathrm{F}}$, respectively, and

229 Lactarius rufus and L. hepaticus are negative and positive indicators for $\mathrm{N}_{\text {TFD }}$, respectively.

230 Nonetheless, genus-level analyses revealed most indicator species patterns hold true at higher

231 taxonomic ranks (Extended Data Fig. 3). In some genera, the aggregate of species acts as

232 indicator, although individual species do not (e.g. Sistotrema, Clavulina and Boletus for $\mathrm{N}_{\mathrm{TFD}}$

233 and $\mathrm{K}_{\mathrm{TFD}}$ ). For several genera we find a different response to elevated $\mathrm{N}_{\mathrm{TFD}}$ than previous

234 studies, even those with consistent responses across studies ${ }^{51}$ (i.e. Tomentella, Tylospora,

235 Cenococcum, Hebeloma, Amanita). Furthermore, we confirm the response to elevated $\mathrm{N}_{\mathrm{TFD}}$

236 of several genera only recorded in few studies ${ }^{51}$ (i.e. Clavulina, Elaphomyces, Boletus,

237 Amphinema).

238 With increasing $\mathrm{N}$ availability, metabolically costly ways of obtaining $\mathrm{N}$ from complex soil

239 organic sources are less cost-effective; fungi that utilise those pathways (e.g. Cortinarius,

240 Piloderma, Tricholoma) are at a disadvantage compared to fungi that utilise inorganic N (e.g.

241 Elaphomyces, Laccaria) ${ }^{51}$. Indeed, organic $\mathrm{N}$ users tended to be negative indicators for $\mathrm{N}$

242 deposition, and inorganic $\mathrm{N}$ users tended to be positive.

243 Some indicator species for $\mathrm{K}_{\mathrm{TFD}}$ are abundant and widespread in Europe (e.g. Elaphomyces

244 asperulus, Lactarius quietus, Piloderma sphaerosporum); however, $\mathrm{K}_{\mathrm{TFD}}$ has not been

245 identified as a key variable in previous EM studies. A meta-analysis showed that in $69 \%$ of

246 experiments tree growth responded positively to soil $\mathrm{K}$ increases ${ }^{52}$, but $\mathrm{K}$ is highly diffusible

247 in soil and easily accessible for plants. Some $\mathrm{K}_{\mathrm{TFD}}$ may originate from canopy leaching; with 
acidifying pollution, $\mathrm{K}$ leaches, and if depleted in foliage and litter, $\mathrm{K}$ availability in soil organic matter could decrease. Moreover, $\mathrm{K}$ is taken up and translocated by EM fungi in a specific manner (e.g. EM fungi with hydrophobins transfer less K) ${ }^{11}$. This agrees with our results; most negative indicator genera were hydrophobic and most positive ones

252 hydrophilic ${ }^{53}$.

253 Based on the large number of indicator species for MAT, climate should play an important 254 role in shaping EM communities, as suggested by fruiting phenology studies ${ }^{54}$. However, it is difficult to distinguish MAT from climate and therefore to know whether a fungus occurs somewhere because of prevalent temperatures. Nevertheless, current habitats may become

257 less favourable for many EM fungi as temperature increases.

258 Accumulated change-point values of all individual EM fungi indicate environmental

259 thresholds of change for most key environmental variables. There was a narrow range for 260 fungi negatively affected by $\mathrm{N}_{\text {TFD }}$ with a sharp threshold at $5.8 \mathrm{~kg} \mathrm{~N} \mathrm{ha}^{-1} \mathrm{yr}^{-1}$. These mainly 261 conifer specialists thrive in poor soils and pre-industrial $\mathrm{N}$ levels (ca. $<2 \mathrm{~kg} \mathrm{~N} \mathrm{ha}^{-1} \mathrm{yr}^{-1}$ ), but cannot keep up with increased $\mathrm{N}_{\mathrm{TFD}}$ from industrial, agricultural and transport emissions over

263 the last decades. They are likely out-competed by fungi that use the additional inorganic $\mathrm{N}$ or 264 avoid additional $\mathrm{N}$ uptake costs ${ }^{55}$, particularly within the temperate distribution ranges of 265 beech and oak where $\mathrm{N}_{\mathrm{TFD}}$ is greatest, and organic $\mathrm{N}$ users show some recovery in fruiting if 266 N pollution decreases ${ }^{56}$. Positively-affected fungi, mostly host generalists lacking proteolytic 267 abilities, initially do well with additional inorganic N, giving them a competitive advantage.

268 However, their much broader response range and less defined peak at $15.5 \mathrm{~kg} \mathrm{~N}^{-1} \mathrm{yr}^{-1}$ 269 suggests adaptation by positively-affected fungi to increased $\mathrm{N}_{\text {TFD }}$ varies greatly. This might 270 be driven by geographically-divergent population-level evolutionary selection pressures on 271 fungi since the industrial revolution. Furthermore, naturally enriched microsites (e.g. animal 
272 latrines, carcasses, disturbances) and macrosites (e.g. stands with $\mathrm{N}_{2}$ fixers) could have pre273 adapted certain fungi.

274 We confirm and extend observations based on fruitbodies and roots at smaller scales ${ }^{57}$ that

275 conifer specialists - most with abundant hyphae and rhizomorphs - are more negatively

276 affected by increasing $\mathrm{N}$ than broadleaf specialists and generalists. The strong differences

277 observed in host specificity between fungi negatively- and positively-affected by $\mathrm{N}_{\text {TFD }}$ may

278 be caused by differences in enzymatic capability to acquire $\mathrm{N}$ directly from complex soil

279 organic compounds, thus circumventing mineralization, and in resource exchange rate, e.g. if

280 specialists transfer more soil $\mathrm{N}$ per unit of tree $\mathrm{C}$ than generalists ${ }^{34}$. Comparative genetic,

281 physiological and ecological studies of the different sets of dominant indicators are now

282 needed to test alternative models of EM community optimisation versus parasitism under

283 changing $\mathrm{C}$ and $\mathrm{N}$ conditions ${ }^{58}$ through species replacement, plasticity and/or evolution ${ }^{59}$.

284 Large-scale below-ground analysis contributes important information on ecosystem

285 assessment tools for a uniquely important guild of forest organisms. Critical loads for

286 eutrophying $\mathrm{N}$ deposition were previously estimated for EM fungi, largely based on expert

287 opinion and above-ground data, at 5-10 $\mathrm{kg} \mathrm{N} \mathrm{ha}^{-1} \mathrm{yr}^{-1}$ for North America ${ }^{36}$ and 10-20 $\mathrm{kg} \mathrm{N}^{-}$

$288{ }^{1} \mathrm{yr}^{-1}$ for Europe ${ }^{60}$. Thresholds based on European EM data have focused on few sites across

289 smaller gradients or EM richness and evenness instead of community composition ${ }^{16,35}$. Our

290 large N deposition gradient leads to a much lower European threshold value for a substantial

291 EM shift at 5-6 $\mathrm{kg} \mathrm{N} \mathrm{ha}^{-1} \mathrm{yr}^{-1}$, based on both throughfall and open field deposition data,

292 approaching recent lower estimates for other forest organisms ${ }^{61,62}$. Caution is needed

293 inferring absolute values for critical loads, but based on our results critical loads for European

294 forests need strong adjustment towards those for North American forests, and EM and forest

295 change thresholds need aligning to explain alarming deterioration in European tree

296 nutrition ${ }^{13}$. Critical $\mathrm{N}: \mathrm{P}_{\mathrm{F}}$ are considered plant specific ${ }^{63}$ and $\mathrm{N}: \mathrm{P}_{\mathrm{F}}$ has been linked to tree 
297 health, with breakpoint values of 7.3 for conifers and 14.8 for broadleaf trees regarding

298 defoliation $^{12}$. We show that lower (10.2) and upper (13.3) $\mathrm{N}: \mathrm{P}_{\mathrm{F}}$ thresholds for $\mathrm{EM}$

299 communities are linked to conifers and broadleaves, respectively. Community threshold

300 forest floor $\mathrm{pH}$ levels for negative and positive indicator species overlap. Although soil $\mathrm{pH}$ is

301 anthropogenically influenced (e.g. liming) and soil acidification affects parts of Europe ${ }^{64}$, the

302 major soil $\mathrm{pH}$ differences across forests arise from soil parent material and climatic

303 differences over long timescales, and must have long influenced EM communities.

304 Nonetheless, individual species could be affected. For $\mathrm{K}_{\mathrm{TFD}}$, no threshold values for EM

305 composition have been published. We identify a 5-8 $\mathrm{kg} \mathrm{K} \mathrm{ha}^{-1} \mathrm{yr}^{-1}$ threshold for declining

306 species; however, $\mathrm{K}_{\mathrm{TFD}}$ results partly from $\mathrm{K}$ uptake and leaching by trees, which may be

307 influenced by EM fungi themselves. Therefore, research into K deposition and cycling is

308 needed for EM communities ${ }^{11}$ and forests ${ }^{52}$.

309 Physiological and morphological heterogeneity and plasticity of EM mycelium have been

310 considered responsible for enabling trees to rapidly take up soil nutrients ${ }^{65,66}$, here we show

311 morphological plasticity within dominant EM taxa and changes over environmental

312 gradients. This has significant implications for functional diversity studies at large-scales

313 and/or across gradients. Indirect assignment of EM functional traits to taxonomic groups

314 merits caution and their temporal variation merits investigation.

315 We conclude that intensive and extensive organismal and environmental data collection, with

316 multiple biotic and abiotic co-varying factors, reveals soil, atmospheric deposition and

317 climate variables control large-scale patterns of species distributions in EM communities.

318 Such data allow linking species and community responses to environmental thresholds acting

319 across macroecological scales and deliver new insights into spatial variation in specificity and

320 functional trait plasticity below-ground.

321 


\section{References}

323 1. Canadell, J. G. et al. Contributions to accelerating atmospheric $\mathrm{CO} 2$ growth from

324 economic activity, carbon intensity, and efficiency of natural sinks. Proc. Natl. Acad. Sci.

325 USA 104, 18866-18870 (2007).

326 2. Galloway, J. N. et al. Transformation of the nitrogen cycle: recent trends, questions, and

327 potential solutions. Science 320, 889 (2008).

328 3. European Union Soil Thematic Strategy. COM(2006) 231 (2006).

329 4. Janssens, I. A. et al. Reduction of forest soil respiration in response to nitrogen 330 deposition. Nature Geosci 3, 315-322 (2010).

331 5. Johnson N. C., Jansa J. Mycorrhizas: At the interface of biological, soil and, earth 332 sciences. Mycorrhizal mediation of soil: Fertility, structure, and carbon storage, 1-6

333 Elsevier, Amsterdam (2017).

334 6. Van der Heijden, M. G. A., Martin, F. M., Selosse, M.-A. \& Sanders, I. R. Mycorrhizal

335 ecology and evolution: the past, the present, and the future. New Phytol. 205, 1406-1423

$336 \quad$ (2015).

337 7. Averill, C., Turner, B. L. \& Finzi, A. C. Mycorrhiza-mediated competition between

338 plants and decomposers drives soil carbon storage. Nature 505, 543-545 (2014).

339 8. Clemmensen, K. E. et al. Roots and associated fungi drive long-term carbon sequestration

$340 \quad$ in boreal forest. Science 339, 1615-1618 (2013).

341 9. Bennett, J. A. et al. Plant-soil feedbacks and mycorrhizal type influence temperate forest

342 population dynamics. Science 355, 181-184 (2017).

343 10. Terrer, C., Vicca, S., Hungate, B. A., Phillips, R. P. \& Prentice, I. C. Mycorrhizal

344 association as a primary control of the $\mathrm{CO}_{2}$ fertilization effect. Science 353, 72-74

345 (2016).

346 11. Smith, S. E. \& Read, D. E. Mycorrhizal Symbiosis, 3rd edn. Academic, London (2008). 
12. Veresoglou, S. D. et al. Exploring continental-scale stand health $-\mathrm{N}: \mathrm{P}$ ratio relationships for European forests. New Phytol. 202, 422-430 (2014).

13. Jonard, M. et al. Tree mineral nutrition is deteriorating in Europe. Glob. Change Biol. 21, $418-430(2015)$.

14. Levin S. A. Multiple scales and the maintenance of biodiversity. Ecosystems 3, 498-506 (2000).

15. Lilleskov, E. A. \& Parrent, J. L. Can we develop general predictive models of mycorrhizal fungal community-environment relationships? New Phytol. 174, 250-256 (2007).

16. Suz, L. M. et al. Environmental drivers of ectomycorrhizal communities in Europe's temperate oak forests. Mol. Ecol. 23, 5628-5644 (2014).

17. Peay, K. G., Matheny P. B. Biogeography of ectomycorrhizal Fungi. In The molecular mycorrhizal symbiosis, F. Martin, ed. John Wiley \& Sons, pp. 341-361. (2017).

18. Cox, F., Barsoum, N., Lilleskov, E. A. \& Bidartondo, M. I. Nitrogen availability is a primary determinant of conifer mycorrhizas across complex environmental gradients. Ecol. Lett. 13, 1103-1113 (2010).

19. Cudlin, P. et al. Fine roots and ectomycorrhizas as indicators of environmental change. Plant Biosyst. 141, 406-425 (2007).

20. Tedersoo, L. et al. Towards global patterns in the diversity and community structure of ectomycorrhizal fungi. Mol. Ecol. 21, 4160-4170 (2012).

21. Ostonen, I. et al. Adaptive root foraging strategies along a boreal-temperate forest gradient. New Phytol. 215, 977-991 (2017).

22. Kauserud, H. et al. Warming-induced shift in European mushroom fruiting phenology. Proc. Natl. Acad. Sci. USA 109, 14488-14493 (2012). 
23. Peay, K. G., Bruns, T. D., Kennedy, P. G., Bergemann, S. E. \& Garbelotto, M. A strong species-area relationship for eukaryotic soil microbes: island size matters for ectomycorrhizal fungi. Ecol. Lett. 10, 470-480 (2007).

24. Peay, K. G., Bidartondo, M. I. \& Arnold, A. E. Not every fungus is everywhere: scaling to the biogeography of fungal-plant interactions across roots, shoots and ecosystems. New Phytol. 185, 878-882 (2010).

25. Suz, L. M. et al. Monitoring ectomycorrhizal fungi at large scales for science, forest management, fungal conservation and environmental policy. Ann. For. Sci. 72, 877-885 (2015).

26. Peay, K. G., Kennedy, P. G., Davies, S. J., Tan, S. \& Bruns, T. D. Potential link between plant and fungal distributions in a dipterocarp rainforest: community and phylogenetic structure of tropical ectomycorrhizal fungi across a plant and soil ecotone. New Phytol. 185, 529-542 (2010).

27. Taylor D. L., Hollingsworth T. N., McFarland J. W., Lennon N. J., Nusbaum C., Ruess R. W. A first comprehensive census of fungi in soil reveals both hyperdiversity and finescale niche partitioning. Ecol. Monogr. 84, 3-20 (2014).

28. Bahram, M., Peay, K. G. \& Tedersoo, L. Local-scale biogeography and spatiotemporal variability in communities of mycorrhizal fungi. New Phytol. 205, 1454-1463 (2015).

29. Kennedy, P. G., Garibay-Orijel, R., Higgins, L. M. \& Angeles-Arguiz, R. Ectomycorrhizal fungi in Mexican Alnus forests support the host co-migration hypothesis and continental-scale patterns in phylogeography. Mycorrhiza 21, 559-568 (2011).

30. Kennedy, P.G. et al. Scaling up: examining the macroecology of ectomycorrhizal fungi. Mol. Ecol. 21, 4151-4154 (2012). 
394 31. Põlme, S. et al. Biogeography of ectomycorrhizal fungi associated with alders (Alnus

395 spp.) in relation to biotic and abiotic variables at the global scale. New Phytol. 198, 1239-

$396 \quad 1249(2013)$.

397 32. Talbot, J. M. et al. Endemism and functional convergence across the North American soil

398 mycobiome. Proc. Natl. Acad. Sci. USA 111, 6341-6346 (2014).

399 33. Tedersoo, L. et al. Global diversity and geography of soil fungi. Science 346, 1256688

$400 \quad$ (2014).

401 34. Molina, R. \& Horton, T. R. Mycorrhiza specificity: Its role in the development and 402 function of common mycelial networks. in Mycorrhizal Networks (ed. Horton, T. R.) 1403 (Springer Netherlands, 2015). doi:10.1007/978-94-017-7395-9_1.

404 35. De Witte, L. C., Rosenstock, N. P., van der Linde, S. \& Braun, S. Nitrogen deposition 405 changes ectomycorrhizal communities in Swiss beech forests. Sci. Total Environ. 605$406 \quad$ 606, 1083-1096 (2017).

407 36. Pardo, L. H. et al. Effects of nitrogen deposition and empirical nitrogen critical loads for 408 ecoregions of the United States. Ecol. Appl. 21, 3049-3082 (2011).

409 37. Hettelingh, J.-P. et al. Effects-based integrated assessment modelling for the support of $410 \quad$ European air pollution abatement policies. in Critical loads and dynamic risk 411 assessments: nitrogen, acidity and metals in terrestrial and aquatic ecosystems (eds. de 412 Vries, W., Hettelingh, J.-P. \& Posch, M.) 613-635 (Springer Netherlands, 2015). 413 doi:10.1007/978-94-017-9508-1_25.

414 38. Reis, S. et al. From acid rain to climate change. Science 338, 1153-1154 (2012).

415 39. Lilleskov, E. A., Hobbie, E. A. \& Horton, T. R. Conservation of ectomycorrhizal fungi: 416 exploring the linkages between functional and taxonomic responses to anthropogenic $\mathrm{N}$ 417 deposition. Fun. Ecol. 4, 174-183 (2011). 
40. Hendershot, J. N., Read, Q. D., Henning, J. A., Sanders, N. J. \& Classen, A. T. Consistently inconsistent drivers of microbial diversity and abundance at macroecological scales. Ecology 98, 1757-1763 (2017).

41. Thompson, L. R. et al. A communal catalogue reveals Earth's multiscale microbial diversity. Nature 551, 457 (2017).

42. Glassman S. I. et al. A continental view of pine-associated ectomycorrhizal fungal spore banks: a quiescent functional guild with a strong biogeographic pattern. New Phytol. 205, 1619-1631 2015).

43. Gardes, M. \& Bruns, T. D. Community structure of ectomycorrhizal fungi in a Pinus muricata forest: above- and below-ground views. Can. J. Bot. 74, 1572-1583 (1996).

44. Anderson, I. C. \& Cairney, J. W. G. Ectomycorrhizal fungi: exploring the mycelial frontier. FEMS Microbiol. Rev. 31, 388-406 (2007)

45. Buée M., Sentausa E., Murat C. Molecular technologies applied to the ecology of ectomycorrhizal communities. in Molecular Mycorrhizal Symbiosis (ed. Martin F.) 323406 (John Wiley \& Sons, Inc., 2016). DOI: 10.1002/9781118951446.ch18.

46. Tedersoo, L. \& Nilsson, R. H. Molecular identification of fungi. in Molecular Mycorrhizal Symbiosis (ed. Martin F.) 299-322 (John Wiley \& Sons, Inc., 2016). DOI:10.1002/9781118951446.ch17.

47. Newton, A. C. \& Haigh, J. M. Diversity of ectomycorrhizal fungi in Britain: a test of the species-area relationship, and the role of host specificity. New Phytol. 138, 619-627 (1998).

48. Peay, K. G. The mutualistic niche: mycorrhizal symbiosis and community dynamics. Annu. Rev. Ecol. Evol. Syst. 47, 143-164 (2016). 
49. Taylor, A. F. S., Fransson, P. M., Högberg, P., Högberg, M. N. \& Plamboeck, A. H.

442 Species level patterns in $13 \mathrm{C}$ and $15 \mathrm{~N}$ abundance of ectomycorrhizal and saprotrophic

443 fungal sporocarps. New Phytol. 159, 757-774 (2003).

444

50. Hortal, S. et al. Role of plant-fungal nutrient trading and host control in determining the competitive success of ectomycorrhizal fungi. ISME J. 11, 2666 (2017).

51. Lilleskov, E. A., Hobbie, E. A. \& Horton, T. R. Conservation of ectomycorrhizal fungi: exploring the linkages between functional and taxonomic responses to anthropogenic $\mathrm{N}$ deposition. Fun. Ecol. 4, 174-183 (2011).

52. Tripler C. E., Kaushal S. S., Likens G. E., Walter M. T. Patterns of potassium dynamics in forest ecosystems. Ecol. Lett. 9, 451-466 (2006).

53. Agerer, R. Exploration types of ectomycorrhizae. Mycorrhiza 11, 107-114 (2001).

54. Boddy, L. et al. Climate variation effects on fungal fruiting. Fun. Ecol. 10, 20-33 (2014).

55. Wallander, H. A new hypothesis to explain allocation of dry matter between mycorrhizal

454 fungi and pine seedlings in relation to nutrient supply. Plant Soil 168, 243-248 (1995).

56. Van Strien, A. J., Boomsluiter, M., Noordeloos, M. E., Verweij, R. J. T. \& Kuyper, T. W. Woodland ectomycorrhizal fungi benefit from large-scale reduction in nitrogen deposition in the Netherlands. J. Appl. Ecol. 55, 290-298 (2018).

57. Arnolds, E. Decline of ectomycorrhizal fungi in Europe. Agric. Ecosyst. Environ. 35, 209-244 (1991).

460 58. Lilleskov, E.A. How do composition, structure, and function of mycorrhizal fungal 461 communities respond to nitrogen deposition and ozone exposure? in The Fungal 462 Community (eds. Dighton, J. White, J.) 769-801 (CRC Press., 2005). changing world: an evolutionary perspective. Ecol. Lett. 13, 1459-1474 (2010). 
60. Bobbink, R. \& Hettelingh, J. P. Effects of nitrogen deposition on woodland, forest and other wooded land (EUNIS class G). in Review and Revision of Empirical Critical Loads and Dose-Response Relationships. RIVM Report 680359002, pp. 135-171 (2017).

61. Giordani, P. et al. Detecting the nitrogen critical loads on European forests by means of epiphytic lichens. A signal-to-noise evaluation. For. Ecol. Manag. 311, 29-40 (2014).

62. Leppänen, S. M., Salemaa, M., Smolander, A., Mäkipää, R. \& Tiirola, M. Nitrogen fixation and methanotrophy in forest mosses along a $\mathrm{N}$ deposition gradient. Env. Exp. Bot. 90, 62-69 (2013).

63. Güsewell, S. N : P ratios in terrestrial plants: variation and functional significance. New Phytol. 164, 243-266 (2004).

64. Cools, N. \& De Vos, B. Availability and evaluation of European forest soil monitoring data in the study on the effects of air pollution on forests. iForest 4, 205-211 (2011).

65. Hazard, C. \& Johnson, D. Does genotypic and species diversity of mycorrhizal plants and fungi affect ecosystem function? New Pythol. (2018) DOI: 10.1111/nph.15010.

66. Chen, W. et al. Root morphology and mycorrhizal symbioses together shape nutrient foraging strategies of temperate trees. Proc. Natl. Acad. Sci. USA 113, 8741-8746 (2016).

Supplementary Information is available in the online version of the paper.

Acknowledgements NERC grant NE/K006339/1 to M.B. and D.O. Analysis partly based on ICPF PCC Database (http://icp-forests.net). ICPF FSCC provided first Level II soil survey data. ICPF PCC and observers, technicians and scientists performed long-term sampling, analyses and environmental data handling largely funded by national institutions and ministries, supported by governmental bodies, services and landowners, and partially EUfunded under Regulation (EC) No.2152/2003 (Forest Focus), project LIFE07ENV/D/000218 
490 (FutMon), and through SWETHRO. Co-financing for D.Ž. and T.G. by P4-0107 (RS Higher

491 Education, Science and Technology Ministry). D. Devey and L. Csiba for laboratory

492 assistance, S. Boersma, F., H. and J. van der Linde, C. Gonzales, A. and R. Lenz, S. Wipf, L.

493 Garfoot, B. Spake, W. Rimington, J. Kowal, T. Solovieva, D. Gane, M. Terrington, J. Alden,

494 A. Otway, V. Kemp, M. Edgar, Y. Lin, A. Drew, E. Booth, P. Cachera, R. De-Kayne, J.

495 Downie, A. Tweedy, E. Moratto, E. Ek, P. Helminen, R. Lievonen, P. Närhi, A. Ryynänen,

496 M. Rupel, J. Draing and F. Heun for field and laboratory work, R. Castilho for

497 bioinformatics, K.-H. Larsson, P.-A. Moreau, J. Nuytinck and M. Ryberg for taxonomy, N.

498 Barsoum, E. Lilleskov, D. Read and T. Kuyper for discussions throughout.

499

500 Author contributions M.B. conceived study. S.V., M.B., F.C., L.S., B.A. led most sampling

501 design and fieldwork. S.V., B.A., L.S., F.C., Y.Z., M.B. processed and analysed samples.

502 H.A., E.A., S.B., N.C., B.D., H.D., J.E., J.G., T.G., K.H., F.J., F.K., P.L., M.M., J.M., H.M.,

503 P.M., M.N., P.P., P.R., M.S., H.S., W.S., V.Š., A.T., I.T., H.T., E.V., A.V., L.V., P.W., S.W.,

504 D.Ž. assisted fieldwork and collected, collated and validated long-term environmental data.

505 S.V., H.G., D.O. performed bioinformatics. S.V., D.O., L.S. performed data analysis. C.C.

506 summarized literature. S.V. drafted manuscript, M.B. provided chief contributions, D.O., L.S.

507 contributed extensively. All authors wrote and reviewed manuscript. S.V., L.S., D.O., M.B.

508 led revision.

509

510 Author information Reprints and permissions information available at

511 www.nature.com/reprints. R code available upon reasonable request. Sequencing data

512 available through DRYAD under doi:10.5061/dryad.cr70qc8. Environmental data available

513 from ICPF but restrictions apply. Data available from authors upon reasonable request with 
514 ICPF permission. Authors declare no competing financial interests. Correspondence and

515 material requests to S.V. (sietse.vanderlinde@forestry.gsi.gov.uk).

516

517 Figure legends

518 Figure 1: Map of Europe showing sampled UNECE ICP Forests Level II plots.

519 Polygons depict outer boundaries of the sampled area for each host tree species.

521 Figure 2: Krona chart of taxonomic affiliation of ectomycorrhizas and their relative

522 abundance. Inner circles represent higher taxonomic ranks, while more detailed taxonomic

523 ranks (up to species level) are presented in outer circles. A full interactive version of this

524 chart is available in the online version of this article (Supplementary Information Fig. 1).

525

526 Figure 3: Variation partitioning Venn diagram showing the percentages of individual

527 contributions of host variables (host species, foliar chemistry and defoliation),

528 soil+deposition variables, climatic variables and geographic distance. Percentage of variance

529 explained by multiple partition models is shown where ellipses overlap. Values in brackets

530 show the total percentage of variance explained by the four partitions. Residual variance

531 represents the percentage unexplained by the four partition models.

532

533 Figure 4: Threshold indicator taxa analyses (TITAN) on individual OTU abundances in

534 response to $\mathrm{N}_{\mathrm{TFD}}$ (a). Black symbols show taxa declining with increasing $\mathrm{N}_{\mathrm{TFD}}\left(\mathrm{z}^{-}\right)$, open

535 symbols depict increasing taxa $\left(\mathrm{z}^{+}\right)$. Symbol size is proportional to magnitude of response (z-

536 score). Horizontal lines represent $5^{\text {th }}$ and $95^{\text {th }}$ quantiles of values resulting in the largest

537 change in taxon z-scores among 1,000 bootstrap replicates. Tree shapes indicate host 
538 generalist, conifer- or broadleaf-specific. Community-level output of accumulated z-scores

539 per plot is shown in response to $\mathrm{N}_{\mathrm{TFD}}(\mathrm{b})$.

540

541 Materials and methods

\section{$542 \quad$ Sampling and processing}

543 Since 1995, the International Co-operative Programme on Assessment and Monitoring of Air

544 Pollution Effects on Forests ${ }^{67,68}$ has been intensively monitoring ca. 800 plots (Level II) in

545 major forest ecosystems across Europe ${ }^{69}$. Their extensive in situ data better reflect the local

546 environmental conditions of plots than regional modelled or extrapolated data ${ }^{70}$. These Level

547 II plots of at least 0.25 ha and located within homogenous forest stands are structurally

548 diverse and cover a representative mixture of European managed forest types (ranging from

549 plantations to natural regenerating forests) ${ }^{71}$. European forests are dominated by Scots pine,

550 Norway spruce and European beech (60\% of EU30 forest area), with the next three most

551 common tree species together covering $10 \%$. We selected all ICP Forests Level II plots

552 where deposition, meteorology, foliar chemistry, soil and preferably soil solution data are

553 measured simultaneously, and between September 2013 and September 2015 we sampled

554 plots with European beech (Fagus sylvatica L.; $\mathrm{n}=35$ ), Norway spruce (Picea abies (L.) H.

555 Karst; $\mathrm{n}=36$ ) or Scots pine (Pinus sylvestris L.; $\mathrm{n}=32)$ as the dominant $(>50 \%$ abundance)

556 tree species. We combined these with additional data similarly collected from Scots pine

557 Level II plots by Cox et al. ${ }^{18}(\mathrm{n}=12)$ and pedunculate and sessile oak (Quercus robur L. and

558 Q. petraea (Matt.) Liebl) by Suz et al. ${ }^{16}(\mathrm{n}=22)$, to give a widespread coverage of European

559 forest areas (Fig. 1).

560 We used Sanger DNA sequencing of the full internal transcribed spacer (ITS) amplicon from

561 individual ectomycorrhizas to maximise resolution of identifications, obtain relative

562 abundance data and link DNA sequences directly to morphology, following the standardized 
563 sampling protocols of Cox et al. ${ }^{18}$ and Suz et al. ${ }^{16}$. Briefly, on each plot $(n=137) 24$ trees of

564 the investigated target tree species were randomly selected and from those trees a transect

565 was made to the nearest tree of the target species, then four soil samples $(25 \mathrm{~cm}$ deep, $2 \mathrm{~cm}$

566 diameter) were collected at equal distances on each transect. When plots contained multiple

567 tree species, areas with non-target tree species were avoided. Soil samples were stored at $4^{\circ} \mathrm{C}$

568 up to ten days until processed. Roots from each soil core were rinsed on a $0.5 \mathrm{~mm}$ sieve, and

569 mycorrhizal roots were collected for five minutes using a dissecting microscope.

570 Subsequently, from each soil sample, an individual mycorrhiza was sampled from the three

571 longest roots, resulting in 288 mycorrhizas per plot. Morphological characteristics of each

572 mycorrhiza were recorded, including presence/absence of emanating hyphae and

573 rhizomorphs, and turgor to assess activity. Genomic DNA from individual mycorrhizas was

574 obtained using Extract-N-Amp (Sigma-Aldrich, St. Louis, MO, USA), and the ITS region of

575 the nuclear rDNA was amplified using $\operatorname{ITS}_{1 F^{72}}$ and ITS4 $4^{73}$ primers. Amplicons were purified

576 using ExoSAP-IT (USB, Cleveland, OH, USA) and sequenced bidirectionally using

577 BigDye3.1 with an ABI 3730 DNA Analyzer (Applied Biosystems, Foster City, CA, USA).

578

579 Environmental data

580 On the Level II plots various environmental long-term measurements (average 14 years) were

581 carried out using national protocols based on a harmonized methodology ${ }^{74}$ (see

582 Supplementary Information Table 2). Soil types were classified in ten types: Andosols,

583 Arenosols, Calcisols, Cambisols, Leptosols, Podzols, Regosols, Umbrisols, soil types

584 characterised by an Argic B horizon (i.e. Luvisols and Alisols), and soils with gleyic

585 properties (i.e. Gleysols and Stagnosols) ${ }^{64,75}$. Whilst maximizing the number of plots without

586 missing values $(\mathrm{n}=108)$, we selected available data including forest age, level of

587 defoliation $^{76}$, geographical coordinates and elevation along with soil (eight variables) and 
588 foliar (seven variables of investigated tree species) ${ }^{77}$ data, atmospheric throughfall deposition

589 chemistry (wet and dry under forest canopy deposition, 11 variables) ${ }^{78}$ and meteorology (six 590 variables $)^{79}$.

591

\section{Bioinformatics}

593 We used Phred ${ }^{80}$ to obtain base quality scores (Q) for both forward and reverse DNA

594 sequences from all individual mycorrhizas, including DNA sequences from Cox et al. ${ }^{18}$ and

595 Suz et al. ${ }^{16}$. The two sequences obtained from each mycorrhiza were assembled in Geneious

596 (version 8.1.8) ${ }^{81}$, with the De Novo Assemble tool. We used Trimmomatic ${ }^{82}$ to remove low

597 quality bases $(\mathrm{Q}<20)$ at either end of the sequences and then discarded short reads $(<100$

598 remaining bp). We then used the uchime_ref tool in vsearch ${ }^{83}$ to match chimeric sequences

599 against the UNITE reference database (version 7.1, 22/08/2016).

600 We used the usearch_global tool in vsearch to identify remaining DNA sequences with a

601 percentage match $\geq 97 \%$ to UNITE 7.1 species hypotheses ${ }^{84}$. From the remaining unmatched

602 sequences, we first removed all sequences with ambiguous base pair codes and then used the

603 cluster_fast tool in vsearch, to identify de novo operational taxonomic unit (OTU) clusters.

604 The unmatched sequences were then matched to the centroids of these de novo clusters;

605 sequences were accepted with a percentage identity $\geq 97 \%$ and the remainder discarded.

606 We used three sources of information for each de novo centroid to confirm the identification

607 of the fungal sequences and to provide tentative classifications. First, we examined the ten

608 best alignments from BLAST searches ${ }^{85}$ of the Genbank nucleotide database. Second, we

609 trained RDP Classifier ${ }^{86}$ against the UNITE 7.1 database and then classified the de novo

610 centroids against the trained database. Third, we used vsearch to obtain the best match of

611 each centroid to the UNITE 7.1 species hypotheses. 
612 Finally, we checked the EM status of all OTUs by comparing the taxonomic classification

613 based on UNITE with the literature ${ }^{87,88}$. When OTUs assigned in UNITE to species

614 hypothesis were identified to a taxonomic level that includes both EM and non-EM fungi

615 (e.g. Agaricomycetes sp.), we retrieved the taxonomic names associated with all UNITE

616 DNA sequences within that species hypothesis to assess the level of uncertainty in the

617 classification of the species hypothesis. We discarded de novo OTUs with less resolved

618 classification: (a) whose classification was distant from known EM fungi, (b) where the root

619 tip morphology suggested possibly dead plant or fungal tissue, and (c) which were based on

620 relatively short sequences $(<150 \mathrm{bp})$. The set of identified EM fungal sequences was then

621 used to construct an abundance matrix of OTUs across sites. We used the Hellinger

622 transformation of proportion abundance ${ }^{89}$ in subsequent analyses. Host specificity of

623 abundant OTUs ( $\geq 50 \mathrm{EM}$ ) was established by scoring occurrence at plots with the different

624 tree hosts. The OTUs occurring with one host tree species in a plot were considered strictly

625 specific and OTUs occurring with both coniferous and broadleaf or with more than two tree 626 species were considered generalists.

628 Statistical analysis

629 We used R (version 3.3.3) for statistical analyses and generating figures ${ }^{90}$.

630 To quantify the importance of host variables, soil and deposition chemistry, climate and

631 geographic distance on EM fungal community composition, variances were partitioned

632 following Borcard et al. ${ }^{91}$ and Legendre \& Legendre ${ }^{92}$. Explanatory variables describing plot

633 and tree characteristics were grouped in the following partitions: (i) host (host species, foliar

634 chemistry and defoliation), (ii) soil and deposition chemistry (soil characteristics and

635 throughfall deposition), (iii) climate (climatic region, mean annual air temperature (MAT),

636 precipitation, growing season length, minimum and maximum annual temperatures, 
637 elevation) and (iv) geographic distance (excluding elevation). The most relevant variables in

638 each partition were found through forward-selection model-building with the redundancy

639 analysis (RDA) method based on AIC and $P<0.05$ using ordistep in the vegan package ${ }^{93}$.

640 Geographic distances are the great circle distances, calculated using the mean Earth radius

641 between the minimum and maximum latitude of plots in this study $(r=6,365 \mathrm{~km})$ with

642 rdist.earth in the fields package ${ }^{94}$. Great circle distances are commonly used in large scale

643 macroecological studies to approach real distances between sampling sites ${ }^{95,96}$. The

644 geographic distance matrix was transformed to rectangular data by extracting spatial vectors

645 with principal coordinates of neighbour matrices (PCNM) using pcnm (vegan). To build the

646 geographic distance model, PCNM vectors accounting for autocorrelation were extracted ( $P$

$647<0.05)$ using MoranI (lctools package) ${ }^{97}$ and forward selected. Variation partitioning was

648 carried out for the 108 plots with the selected environmental data using varpart (vegan).

649 Global non-metric multi-dimensional scaling (NMDS) ordinations were used to explore and

650 visualise the main factors affecting EM fungal community composition with metaMDS

651 (vegan). Environmental variables (Supplementary Information Table 2) were fitted to the

652 ordination plots using envfit (vegan). Ordinations were performed for the 108 plots with the

653 selected environmental data. In order to limit co-linearity effects between variables, we

654 selected key environmental variables from the envfit results with $R^{2}>0.4$ and $P<0.01$. In

655 case of correlations $(r \geq 0.7)$ between those variables, the most commonly measured

656 environmental variable (Supplementary Information Table 1) was selected: $\mathrm{N}$ throughfall

657 deposition $\left(\mathrm{N}_{\mathrm{TFD}}\right)$, forest floor $\mathrm{pH}, \mathrm{MAT}, \mathrm{K}$ throughfall deposition $\left(\mathrm{K}_{\mathrm{TFD}}\right)$ and foliar $\mathrm{N}: \mathrm{P}$ ratio

$658 \quad\left(\mathrm{~N}: \mathrm{P}_{\mathrm{F}}\right)$

659 Indicator species for the key environmental variables were detected and their threshold values

660 were calculated using threshold indicator species analyses (TITAN2) ${ }^{98}$. The sums of the

661 indicator species scores of all OTUs were used to detect lower and upper EM community 
662 thresholds for key environmental variables. In addition to $\mathrm{N}_{\text {TFD }}$ we also obtained $\mathrm{EM}$

663 community thresholds for $\mathrm{N}$ open field deposition since open field deposition measurements

664 better reflect the data that is available in spatially mapped deposition datasets ${ }^{99,100}$.

665 G-tests were performed to test if host species or soil type influence hyphal and rhizomorph

666 presence or absence. We used logistic regression with each key environmental variable and

667 the presence or absence of emanating hyphae and rhizomorphs within individual OTUs to test

668 for environmental influences on their morphological plasticity. We considered OTUs where

669 the indicator analysis suggested a response to a particular environmental variable and, for

670 statistical power, we only tested OTUs with $\geq 15 \%$ presence and $\geq 15 \%$ absence of

671 emanating hyphae or rhizomorphs (Extended Data Table 1). Target tree species and soil type

672 was used as co-variate, to account for potential variation in hyphal and rhizomorph

673 development in mycorrhizas belonging to the same OTU among different tree species and

674 different soil types.

675 Code availability, R scripts for data analyses are available from the corresponding author 676 upon reasonable request.

677 Data availability, Sequencing data generated during the current study are available through

678 DRYAD under doi:10.5061/dryad.cr70qc8. Morphological characteristic and host specificity

679 data generated during the current study are available from the corresponding author upon

680 reasonable request. All environmental data (including deposition, foliar chemistry, soil and

681 meteorological data) are available from UNECE ICP Forests but restrictions apply to the

682 availability of these data, which were used under license for the current study. Data are

683 available from the corresponding author upon reasonable request and with permission of

684 UNECE ICP Forests.

685 
686

67. UNECE International Co-operative Programme on Assessment and Monitoring of Air Pollution Effects on Forests. URL http://icp-forests.net/

68. Ferretti, M. \& Fischer, R. Methods for terrestrial investigations in Europe with an overview of North America and Asia. Forest Monitoring, Vol. 12, 1st edn. Elsevier, Amsterdam (2013).

69. De Vries, W., et al. Intensive monitoring of forest ecosystems in Europe - 1. Objectives, set-up and evaluation strategy. For. Ecol. Manag. 174, 77-95 (2003).

70. Dirnböck, T. et al. Forest floor vegetation response to nitrogen deposition in Europe. Glob. Change Biol. 20, 429-440 (2014).

71. Ministerial Conference on the Protection of Forests in Europe (2007).

72. Gardes, M. \& Bruns, T. D. ITS primers with enhanced specificity for basidiomycetes application to the identification of mycorrhizae and rusts. Mol. Ecol. 2, 113-118 (1993).

73. White, T. J., Bruns, T., Lee, S. \& Taylor, J. Amplification and direct sequencing of fungal ribosomal RNA genes for phylogenetics. in PCR Protocols: a guide to methods and applications (eds. Innis, M. A., Gelfand, D. H., Sninsky, J. J. \& White, T. J.) 315-322 (Academic Press, New York, 1990).

74. UNECE ICP Forests Programme Co-ordinating Centre: Manual on methods and critera for harmonized sampling, assessment, monitoring and analysis of the effects of air pollution on forests. Thünen Institute for Forest Ecosystems, Eberswalde, (2016) URL http://icp-forests.org/Manual.htm

75. IUSS Working Group WRB. 2015. World reference base for soil resources 2014, update 2015. International soil classification system for naming soils and creating legends for soil maps. World Soil Resources Reports No. 106. FAO, Rome (2015).

76. Eichhorn, J., et al. Visual assessment of crown condition and damaging agents. In, Manual on methods and criteria for harmonized sampling, assessment, monitoring and 
711 analysis of the effects of air pollution on forests, UNECE ICP Forests Programme Co-

712 ordinating Centre, Eberswalde, p. 54 (2016).

713 77. Rautio, P., Fürst, A., Stefan, K. \& Bartels, U. Sampling and analyses of needles and

714 leaves. In, Manual on methods and criteria for harmonized sampling, assessment,

715 monitoring and analysis of the effects of air pollution on forests. UNECE ICP Forests

716 Programme Co-ordinating Centre, Eberswalde, p. 19 (2016).

717 78. Waldner et al. Detection of temporal trends in atmospheric deposition of inorganic

718 nitrogen and sulphate to forests in Europe. Atmos. Environ. 95, 363-374 (2014).

719 79. Raspe, S., Beuker, E., Preuhsler, T. \& Bastrup-Birk, A., Meteorological measurements.

720 In, Manual on methods and criteria for harmonized sampling, assessment, monitoring and

721 analysis of the effects of air pollution on forests. UNECE ICP Forests Programme Co-

722 ordinating Centre, Eberswalde, p. 35 (2016).

723 80. Ewing, B. \& Green, P. Basecalling of automated sequencer traces using phred. II. Error

724 probabilities. Genome Res. 8, 186-194 (1998).

725 81. Kearse, M. et al. Geneious Basic: an integrated and extendable desktop software platform

726 for the organization and analysis of sequence data. Bioinformatics 28, 1647-1649 (2012)

727 82. Bolger, A. M., Lohse, M. \& Usadel B. Trimmomatic: a flexible trimmer for Illumina

728 sequence data. Bioinformatics 30, 2114-2120 (2014).

729 83. Rognes, T., Flouri, T., Nichols, B., Quince, C. \& Mahé F. VSEARCH: a versatile open

$730 \quad$ source tool for metagenomics. PeerJ Preprints 4, e2409v1 (2016).

731 84. Kõljalg et al. Towards a unified paradigm for sequence-based identification of fungi.

$732 \quad$ Mol. Ecol. 22, 5271-5277 (2013).

733 85. Altschul, S. F., Gish, W., Miller, W., Myers, E. W. \& Lipman, D. J. Basic local alignment

734 search tool. J. Mol. Biol. 215, 403-410 (1990). 
735

736

737

738

739

740

741

742

743

744

745

746

747

748

749

750

751

752

753

754

755

756

757

758

759

86. Wang, Q., Garrity, G. M., Tiedje, J. M. \& Cole, J. R. Naïve Bayesian classifier for rapid assignment of rRNA sequences into the new bacterial taxonomy. Appl. Environ. Microbiol. 73, 5261-7 (2007).

87. Rinaldi, A. C., Comandini, O. \& Kuyper, T. W. Ectomycorrhizal fungal diversity: seperating the wheat from the chaff. Fungal Div. 33, 1560-2745 (2008).

88. Tedersoo, L., May, T. W. \& Smith, M. E. Ectomycorrhizal lifestyle in fungi: global diversity, distribution, and evolution of phylogenetic lineages. Mycorrhiza 20, 217-263 (2010).

89. Legendre, P. \& Gallagher, E. D. Ecologically meaningful transformations for ordination of species data. Oecologia 129, 271-280 (2001).

90. R Core Team. R: A language and environment for statistical computing. R Foundation for Statistical Computing, Vienna, Austria http://www.R-project.org/ (2016).

91. Borcard, D., Legendre, P. \& Drapeau, P. Partialling out the spatial component of ecological variation. Ecology 73, 1045-1055 (1992).

92. Legendre, P. \& Legendre, L. Numerical Ecology, 2nd edn. Springer, Amsterdam (1998).

93. Blanchet, F. G., Legendre, P. \& Borcard, D. Forward selection of explanatory variables. Ecology 89, 2623-2632 (2008).

94. Fields Development Team. fields: Tools for Spatial Data. National Center for Atmospheric Research, Boulder, CO. http://www.cgd.ucar.edu/Software/Fields (2006).

95. Lee et al. On the post-glacial spread of human commensal Arabidopsis thaliana. Nature Comm. DOI:10.1038/ncomms14458 (2017).

96. Lamb et al. Climate-driven mitochondrial selection: a test in Australian songbirds, Mol. Ecol. DOI: 10.1111/mec.14488 (2018).

97. Kalogirou, S. lctools: Local correlation, spatial inequalities, geographically weighted regression and other tools http://lctools.science/ (2016). 
98. Baker, M. E. \& King, R. S. A new method for detecting and interpreting biodiversity and ecological community thresholds. Meths. Ecol. Evol. 1, 25-37 (2010).

99. Dore, A. J. et al. Evaluation of the performance of different atmospheric chemical transport models and inter-comparison of nitrogen and sulphur deposition estimates for the UK. Atmospheric Environ. 119, 131-143 (2015).

100. Dirnböck, T. et al. Forest floor vegetation response to nitrogen deposition in Europe. Glob. Change Biol. 20, 429-440 (2014).

\section{Extended table titles and legends}

\section{Extended Data Table 1. Envfit results for the environmental variables used in the} NMDS ordination. Significant variables are printed bold.

\section{Extended Data Table 2: Observed and expected frequencies of hyphae and rhizomorph} presence for host tree species (a) and soil type (b). S1 = Fe Al soils, S2 = Clay soils, S3 = Soils with little or no differentiation, S4 = Salt accumulation soils, S5 = Organic accumulation soils, $\mathrm{S} 6=$ Limited root soil.

\section{Extended Data Table 3: Effects of key variables on hyphal plasticity for 97\% sequence} similarity OTUs (a) and 99\% sequence similarity OTUs (b). $P$ values $<0.05$ are printed bold. Logistic regressions were only calculated for OTUs where the indicator analysis suggested a response to a particular environmental variable. With: ${ }^{-}=$declining indicator $(z-),{ }^{+}=$ increasing indicator $\left(\mathrm{z}^{+}\right), \downarrow=$ negative correlation, $\boldsymbol{\uparrow}=$ positive correlation.

Extended Data Table 4: Effects of key variables on rhizomorph plasticity for $97 \%$ sequence similarity OTUs (a) and 99\% sequence similarity OTUs (b). $P$ values $<0.05$ are 
printed bold. Logistic regressions were only calculated for OTUs where the indicator analysis

786 suggested a response to a particular environmental variable. With: ${ }^{-}=$declining indicator (z-),

$787+=$ increasing indicator $\left(\mathrm{z}^{+}\right), \downarrow=$ negative correlation, $\boldsymbol{\uparrow}=$ positive correlation.

\section{Extended Data Table 5: Effects of key variables on hyphal and rhizomorph presence on}

790 the total EM community. $P$ values $<0.05$ are printed bold. With: $\downarrow$ = negative correlation, $\uparrow$

$791=$ positive correlation.

792

793 Extended data figures

794 Extended Data Figure 1: Global non-metric multidimensional scaling ordination of

795 community composition showing plots with host trees (brown squares: beech; blue circles:

796 oak; green triangles: pine; yellow diamonds: spruce). Isoclines depict the forest floor $\mathrm{pH}$ and

797 arrows show the direction and strength of correlation of the most influential environmental

798 variables according to their $R^{2}$ values $(>0.4) . \mathrm{A}=$ MAT; $\mathrm{B}=$ mean minimum annual air

799 temperature; $\mathrm{C}=$ growing season length; $\mathrm{D}=\mathrm{NH}_{4}$ throughfall deposition; $\mathrm{E}=\mathrm{N}_{\mathrm{TFD}}$.

800

801

Extended Data Figure 2: Threshold indicator taxa analyses (TITAN) on individual OTU

802 abundances in response to $\mathrm{N}: \mathrm{P}_{\mathrm{F}}(\mathrm{a})$, forest floor $\mathrm{pH}(\mathrm{c}), \mathrm{K}_{\mathrm{TFD}}(\mathrm{e})$ and MAT (g). Black

803 symbols correspond to taxa declining with the increasing variable ( $\left.\mathrm{z}^{-}\right)$, open symbols depict

804 increasing taxa $\left(z^{+}\right)$. Symbol size is proportional to magnitude of response (z-score).

805 Horizontal lines represent $5^{\text {th }}$ and $95^{\text {th }}$ quantiles of values resulting in the largest change in

806 taxon z-scores among 1,000 bootstrap replicates. Tree shapes indicate host generalist,

807 conifer- or broadleaf-specific. Community-level output of accumulated z-scores per plot is

808 shown in response to $\mathrm{N}: \mathrm{P}_{\mathrm{F}}(\mathrm{b})$, forest floor $\mathrm{pH}(\mathrm{d}), \mathrm{K}_{\mathrm{TFD}}(\mathrm{f})$ and MAT (h).

809 
810 Extended Data Figure 3: Threshold indicator taxa analysis at the genus level in response

811 to $\mathrm{N}_{\text {TFD }}(\mathrm{a}), \mathrm{N}: \mathrm{P}_{\mathrm{F}}(\mathrm{c})$, forest floor $\mathrm{pH}(\mathrm{e}), \mathrm{K}_{\mathrm{TFD}}(\mathrm{g})$ and MAT (i). Black symbols correspond to

812 taxa that declined with the increasing variable $\left(\mathrm{z}^{-}\right)$, open symbols depict increasing taxa $\left(\mathrm{z}^{+}\right)$.

813 Symbol size is proportional to magnitude of response (z-score). Horizontal lines represent $5^{\text {th }}$

814 and $95^{\text {th }}$ quantiles of values resulting in the largest change in taxon z-scores among 1,000

815 bootstrap replicates. The community-level output of the accumulated z-scores per plot is

816 shown in response to $\mathrm{N}_{\text {TFD }}(\mathrm{b}), \mathrm{N}: \mathrm{P}_{\mathrm{F}}(\mathrm{d})$, forest floor $\mathrm{pH}(\mathrm{f}), \mathrm{K}_{\mathrm{TFD}}(\mathrm{h})$ and MAT (j). 